\title{
Effects of slow-release urea on in vitro rumen fermentation parameters, growth performance, nutrient digestibility and serum metabolites of beef cattle
}

\section{Efeitos da uréia de liberação lenta nos parâmetros de fermentaçãono do rúmen em vitro, desempenho de crescimento, digestibilidade dos nutrientes e metabolitos séricos de gado de corte}

\author{
Huan Liang ${ }^{1 *}$; Erlong Zhao ${ }^{2}$; Chunyan Feng ${ }^{3}$; Jianfei Wang ${ }^{3}$; Lanjiao $\mathrm{Xu}^{1}$; \\ Zengmin $\mathrm{Li}^{2}$; Shitang Yang ${ }^{4}$; Yu Ge${ }^{2}$; Lizhi $\mathrm{Li}^{2}$; Mingren $\mathrm{Qu}^{5 *}$
}

\section{Highlights:}

Supplementing SRU in diet did not affect the steady-state of rumen environment.

SRU supplementation increased the apparent digestibility of DM and OM of beef cattle.

Some soybean meal could be replaced by SRU in the production of beef cattle.

\begin{abstract}
Two experiments were conducted to investigate the effects of slow-release urea (SRU) on in vitro rumen fermentation parameters, growth performances, nutrient digestibility, and serum metabolites of beef cattle. The single factor design was applied in both experiments. Three diets with different nitrogen sources including soybean meal (Control group), slow-release urea (SRU group), and common urea (Urea group) was designed (concentrate to forage ratio was 4:6). The diets were formulated to be isoenergetic and isonitrogenous, $75 \%$ of the soybean meal in the control diet was replaced by $1.41 \%$ SRU and $1.15 \%$ urea in SRU group and Urea group, respectively. In experiment 1, five healthy Jinjiang cattle (average body weight (BW) was $380 \pm 17.1 \mathrm{~kg}$ ) with permanent rumen fistulas were used in in vitro ruminal fermentation experiment. The results showed that supplementing SRU increased the dry matter degradation rate (DMD), digestible organic matter (DOM) and propionic acid concentration in cultivated fluid, and SRU supplementation decreased $\mathrm{pH}, \mathrm{NH}_{3}-\mathrm{N}$, total volatile fatty acid (TVFA), acetic acid, butyric acid concentration and microbial growth efficiency (MOEFF) in cultivated fluid. In experiment 2, eighteen Simmental crossbred cattle BW=315 $\pm 5.2 \mathrm{~kg}$ ) were stratified by BW and then assigned to the three groups to have equal BW among groups. The results showed that supplementing SRU reduced the average dry matter intake (ADMI), apparent digestibility of ether extract (EE), the activity of glutathione peroxidase (GSH-Px), the levels of IgG and IgA, and the production of thiiodothronine (T3) in serum, SRU supplementation increased the apparent digestibility of dry matter
\end{abstract}

\footnotetext{
1 Researchers. Drs., Jiangxi Provincial Institute of Feed Science, Key Laboratory of Animal Nutrition, Feed Engineering Research Center, Jiangxi Agricultural University, JAU, Nanchang, China. Email: lianghuan22@163.com; xulanjiao1314@163.com

2 Students, Jiangxi Provincial Institute of Feed Science, Key Laboratory of Animal Nutrition, Feed Engineering Research Center, Jiangxi Agricultural University, JAU, Nanchang, China. Email: 841786429@qq.com; 95354969@qq.com; 930857794@ qq.com; 417570279@qq.com

3 Researchers, Menon Animal Nutrition Technology Co., Ltd, MANT, Shanghai, China. Email: fengchunyan323@163.com; wjf_ menon_tech@163.com

4 Researcher, National Beef Cattle Industrial Technology System of Gaoan Test Station, NBCITS, Gaoan, China. Email: yufengnongmu@163.com

5 Prof. Dr., Jiangxi Provincial Institute of Feed Science, Key Laboratory of Animal Nutrition, Feed Engineering Research Center, Jiangxi Agricultural University, JAU, Nanchang, China. Email: qumingren@sina.com

$\dagger^{*}$ Author for correspondence
} 
and organic matter (OM) and alanine aminotransferase (ALT) concentration in serum. These results indicated that some soybean meal could be replaced by SRU and urea in the production of beef cattle. In addition, compared with urea, SRU had a good sustained-release effect. The replacement of some soybean meal by SRU in the diet had no adverse impact on rumen fermentation, growth performance, and serum metabolites of beef cattle.

Key words: Beef cattle. Slow-release urea. Ruminal fermentation. Growth performance. Serum metabolites.

\section{Resumo}

Os dois experimentos foram conduzidos para investigar os efeitos da uréia de liberação lenta nos parâmetros de fermentaçãono do rúmen em vitro, desempenho de crescimento, digestibilidade dos nutrientes e metabolitos séricos de gado de corte. O design de fator único foi aplicado em ambos os experimentos. As três dietas com diferentes fontes de nitrogênio, incluindo farelo de soja (Grupo de controle), uréia de liberação lenta (Grupo de uréia de liberação lenta) e uréia comum (Grupo de uréia) foi designado (concentre-se em relação forrageira foi de 4: 6). As dietas foram formuladas para serem isoenergéticas e isonitrógenas, $75 \%$ da farinha de soja na dieta controle foi substituída por $1,41 \%$ de uréia de liberação lenta e 1,15\% de uréia no Grupo uréia de liberação lenta e Grupo uréia, respectivamente. No experimento 1, cinco gados Jinjiang saudáveis (peso corporal médio (PC) de $380 \pm 17,1 \mathrm{~kg}$ ) com fístulas ruminais permanentes foram utilizadas no experimento de fermentação do rúmen em vitro. Os resultados mostraram que a suplementação de uréia de liberação lenta aumentou a taxa de degradação da substância seca, substância orgânica digestível e concentração de ácido propiônico no líquido cultivado, e a suplementação de SRU diminuiu o pH, NH3-N, ácido graxo volátil total, ácido acético, concentração de ácido butírico e eficiência de crescimento microbiano no fluido cultivado. No experimento 2, dezoito gados mestiços Simmental ( $\mathrm{PC}=315 \pm 5,2 \mathrm{~kg}$ ) foram estratificados por PC e, em seguida, atribuído aos três grupos para ter PC igual entre os grupos. Os resultados mostraram que a suplementação de uréia de liberação lenta reduziu a ingestão média da substância seca, digestibilidade aparente do extrato etéreo, a atividade da glutationa peroxidase, os níveis de $\operatorname{IgG}$ e $\operatorname{IgA}$, e a produção de tiiodotronina (T3) no soro, a suplementação de uréia de liberação lenta aumentou a digestibilidade aparente da concentração de substância seca e substância orgânica e concentração de alanina aminotransferase no soro. Esses resultados indicaram que algum farelo de soja pode ser substituída por uréia de liberação lenta e uréia na produção de gado de corte. Além disso, comparado com a uréia, uréia de liberação lenta teve um bom efeito de liberação sustentada. A substituição de algum farelo de soja por uréia de liberação lenta na dieta não teve impacto adverso na fermentação ruminal, desempenho de crescimento e metabolitos séricos de gados de corte.

Palavras-chave: Gados de corte. Uréia de liberação lenta. Fermentação ruminal. Desempenho de crescimento. Metabólitos séricos.

\section{Introduction}

In recent years, as the rapid development of animal husbandry, the shortage of protein feedstuffs has become a global problem. It is urgent to find a new protein feedstuffs resource to replace soybean meal. Rumen microorganisms can utilize nonprotein nitrogen (NPN) such as ammonia $\left(\mathrm{NH}_{3}\right)$ to synthesize rumen microbial proteins for ruminants (Jin et al., 2018), which makes it possible for ruminants to utilize NPN. Considering the low cost and the availability of nitrogen supplying for ruminal bacteria, urea is an ideal and attractive protein replacement (Ribeiro, Vasconcelos, Morais, Ítavo, \& Franco, 2011), and it has been used as an NPN source in cattle (Grant, 1979). For beef cattle which ingesting low-quality roughage, urea can be used to replace soya bean meal as protein supplements to enhance ruminal degradable protein (Cappellozza et al., 2013). However, the hydrolysis 
rate of urea in rumen is speedy and have exceeded the $\mathrm{NH}_{3}$ utilization rate of rumen microorganism, and the excess $\mathrm{NH}_{3}$ may be harmful to the animal (Ribeiro et al., 2011; Lizarazo, Mendoza, Kú, Melgoza, \& Crosby, 2014; Cherdthong, Wanapat, \& Wachirapakorn, 2011). The adverse effects of urea can be prevented by using SRU (Taylor-Edwards et al., 2009). Goulart et al. (2013) found that SRU can effectively promote the utilization of degrading nitrogen by rumen microorganisms and enhance the ability of rumen microbe to synthesize protein, and SRU can be used as a better NPN feed.

However, the slow-release urea produced by different technologies will have different effects on the use of ruminants. Besides, little information has been focus on the effects of slow-release urea on the serum metabolites in beef cattle. This experiment was conducted systematically to investigate the effects of slow-release urea on in vitro ruminal fermentation, growth performance, nutrient digestibility, and serum metabolites of beef cattle.
The results of this study could provide a scientific foundation for the application of slow-release urea in beef cattle.

\section{Materials and Methods}

In vitro rumen fermentation study (Experiment 1)

Materials, animals and experimental design

All procedures were specially approved by the ethics committee of Jiangxi Agricultural University. Slow-release urea and urea were provided by Menon Animal Nutrition Technology Co., Ltd (Shanghai, China). Five Jinjiang yellow cattle (BW=380 \pm 17.1 $\mathrm{kg}$ ) with permanent rumen fistulas were used for the collection of rumen fluid. The cattle were kept in a single stall and fed twice a day (08: 00 and 18: 00) with free access to water. According to Chinese feeding standard of beef cattle (NY/T815-2004), the composition and nutritional levels of fermentation substrate in each group were shown in Table 1.

Table 1

Composition and nutrient levels of fermentation substrate (DM basis)

\begin{tabular}{lccc}
\hline Items & Control group & SRU group & Urea group \\
\hline Ingredients (\%) & & & \\
Gass silage & 60.00 & 60.00 & 60.00 \\
Corn & 24.16 & 33.09 & 32.50 \\
Wheat bran & 2.62 & 0.67 & 1.52 \\
Soybean meal & 11.12 & 2.73 & 2.73 \\
Slow-release urea & 0.00 & 1.41 & 0.00 \\
Urea & 0.00 & 0.00 & 1.15 \\
NaHCO & 0.25 & 0.25 & 0.25 \\
NaCl & 0.25 & 0.25 & 0.25 \\
Pre-mix & 1.60 & 1.60 \\
Total & 1.60 & 100 & 100 \\
Nutrient composition (\%) & 100 & & 53.56 \\
DM & & 53.36 & 13.59 \\
CP & 53.59 & 13.57 & 2.90 \\
EE & 13.58 & 2.89 & 46.96 \\
NDF & 3.08 & 46.66 &
\end{tabular}

continue 
continuation

\begin{tabular}{lccc} 
ADF & 19.16 & 18.36 & 18.44 \\
Ash & 7.40 & 6.90 & 6.93 \\
NEmf $\left(\mathrm{MJ} \mathrm{kg}^{-1}\right)^{\mathrm{b}}$ & 5.93 & 5.92 & 5.94 \\
\hline
\end{tabular}

${ }^{\mathrm{a}}$ The pre-mix provided the following nutrients per kg of the diet:1500 mg kg-1 Mn, $2000 \mathrm{mg} \mathrm{kg}^{-1} \mathrm{Zn}, 3200 \mathrm{mg} \mathrm{kg}^{-1} \mathrm{Fe}, 650 \mathrm{mg} \mathrm{kg}{ }^{-1}$ $\mathrm{Cu}, 10 \mathrm{mg} \mathrm{kg}^{-1} \mathrm{Se}, 35 \mathrm{mg} \mathrm{kg}^{-1} \mathrm{I}, 10 \mathrm{mg} \mathrm{kg}{ }^{-1} \mathrm{Co}, 3000 \mathrm{mg} \mathrm{kg}^{-1}$ vitamin E, $20000 \mathrm{IU} \mathrm{kg}^{-1}$ vitamin D, $150000 \mathrm{IU}_{\mathrm{kg}}^{-1} \mathrm{vitamin} \mathrm{A,} 130$ $\mathrm{g} \mathrm{kg}^{-1} \mathrm{Ca}$, and $30 \mathrm{~g} \mathrm{~kg}^{-1} \mathrm{P}$.

${ }^{\mathrm{b}}$ NEmf was calculate according to the Chinese Feeding Standard of Beef Cattle (NY/T815-2004). while the other nutrient levels were measured values.

$\mathrm{SRU}=$ Slow-release urea, $\mathrm{DM}=$ Dry matter, $\mathrm{CP}=$ Crude protein, $\mathrm{EE}=$ Ether extract, $\mathrm{NDF}=\mathrm{Neutral}$ detergent fiber, $\mathrm{ADF}=\mathrm{Acid}$ detergent fiber.

The fermentation substrate including soybean meal group (Control), slow-release urea group and common urea group was designed (concentrate to forage ratio was $4: 6$ ). The diets were formulated to be isoenergetic and isonitrogenous, $75 \%$ of the soybean meal in control diet was replaced by $1.41 \%$ SRU and $1.15 \%$ urea in SRU group and Urea group, respectively.

In vitro ruminal fermentation and analytical methods

The rumen liquids were filtered through four lays of cheesecloth and mixed $(1: 2 \mathrm{v} / \mathrm{v})$ with anaerobic buffer (Cone, van Gelder, Visscher, \& Oudshoorn, 1996). All manipulations were done under continuous flushing with $\mathrm{CO}_{2}$. The $500 \mathrm{~mL}$ serum bottles were added with $100 \mathrm{~mL}$ of rumen fluid, 2.5 $\mathrm{g}$ of fermentation substrate, and $200 \mathrm{~mL}$ of buffered rumen fluid for in vitro rumen fermentation. Bottles were closed and incubated at $39^{\circ}$ for $24 \mathrm{~h}$. All samples were incubated in triplicate. A blank (rumen fluid without sample) was incubated in duplicate for the correction of residual dry matter (DM) in samples. The gas production during fermentation was recorded by quickly reading the scale value $(\mathrm{mL})$ of the piston every 2 hours. Fermentation was terminated by placing the bottles on the ice, and the residue was filtered using pre-weighed glass crucibles under vacuum for the determination of in vitro DM digestibility (IVDMD). The ruminal $\mathrm{pH}$ of samples filtrated was determined immediately.
One milliliter of ruminal fluid was preserved by adding $1 \mathrm{~mL}$ of deproteinizing solution $\left(100 \mathrm{~g} L^{-1}\right.$ metaphosphoric acid and $0.6 \mathrm{~g} L^{-1}$ crotonic acid) to determine VFA. Ten milliliters of the filtrate was preserved to determine the ammonia-N concentration and microbial protein synthesis.

The samples were analyzed for DM by drying at $65^{\circ} \mathrm{C}$ for $72 \mathrm{~h}$. Ammonia-N content in the samples was analyzed according to Weatherburn (1967). The VFA concentrations in the samples were determined by gas chromatography (GC-2014; Shimadzu, Kyoto, Japan). Crotonic acid was used as an internal standard. Fermentation liquid microbial protein (FLMCP) synthesis was analyzed according to Makkar, Sharma, Dawra and Negi (1982). The calculation of daily microbial nitrogen production (DMNP) is obtained by dividing the measured MCP content by 6.25 . Rumen microbial growth efficiency $($ MOEFF $)=$ DMNP / DOM.

\section{Feeding study (Experiment 2)}

Animals, diets, and experimental design

Eighteen 7-month-old healthy Simmental hybrid cattle (mean BW was $315 \pm 5.1 \mathrm{~kg}$ ) were used in this feeding study. This trial included a 14day adaptation period and a 60-day formal study period. Cattle were stratified by $\mathrm{BW}$ and then assigned to the three groups: soybean meal group, slow-release urea group and common urea group. The diets were formulated to be isoenergetic and isonitrogenous, $75 \%$ of the soybean meal in control 
diet was replaced by $1.41 \%$ SRU and $1.15 \%$ urea in SRU group and Urea group, respectively. Cattle were untethered in individual stalls and fed with a $400 \mathrm{~g} \mathrm{~kg}^{-1}$ concentrate diet in quantities sufficient to provide ad libitum consumption. According to Chinese feeding standard of beef cattle (NY/
T815-2004), the composition and nutritional levels of the experimental diets in each group were shown in Table 2. Concentrate and roughage were separately offered twice daily at 06:00 $\mathrm{h}$ and 16:00 h. Freshwater was available for ad libitum consumption throughout the study.

Table 2

Composition and nutrient levels of experimental diets (DM basis)

\begin{tabular}{lccc}
\hline Items & Control group & SRU group & Urea group \\
\hline Ingredients (\%) & & & \\
Gass silage & 60.00 & 60.00 & 60.00 \\
Corn & 24.16 & 33.09 & 32.50 \\
Wheat bran & 2.62 & 0.67 & 1.52 \\
Soybean meal & 11.12 & 2.73 & 2.73 \\
Slow-release urea & 0.00 & 1.41 & 0.00 \\
Urea & 0.00 & 0.00 & 1.15 \\
NaHCO & 0.25 & 0.25 & 0.25 \\
NaCl & 0.25 & 0.25 & 0.25 \\
Pre-mix & 1.60 & 1.60 \\
Total & 1.60 & 100 & 100 \\
Nutrient composition (\%) & 100 & & 53.56 \\
DM & & 53.36 & 13.59 \\
CP & 53.59 & 13.57 & 2.90 \\
EE & 13.58 & 2.89 & 46.96 \\
NDF & 3.08 & 46.66 & 18.44 \\
ADF & 47.78 & 18.36 & 6.93 \\
Ash & 19.16 & 6.90 & 5.94 \\
NEmf $\left(\mathrm{MJ} \mathrm{kg}^{-1}\right)^{\mathrm{b}}$ & 7.40 & 5.92 & \\
\hline
\end{tabular}

${ }^{\mathrm{a}}$ The pre-mix provided the following nutrients per kg of the diet:1500 mg kg-1 Mn, $2000 \mathrm{mg} \mathrm{kg}^{-1} \mathrm{Zn}^{-3200 \mathrm{mg} \mathrm{kg}^{-1} \mathrm{Fe}, 650 \mathrm{mg} \mathrm{kg}}$ $\mathrm{Cu}, 10 \mathrm{mg} \mathrm{kg}^{-1} \mathrm{Se}, 35 \mathrm{mg} \mathrm{kg}^{-1} \mathrm{I}, 10 \mathrm{mg} \mathrm{kg}^{-1} \mathrm{Co}, 3000 \mathrm{mg} \mathrm{kg}{ }^{-1}$ vitamin E, $20000 \mathrm{IU} \mathrm{kg}^{-1}$ vitamin D, 150000 IU kg-1 vitamin A, 130 $\mathrm{g} \mathrm{kg}^{-1} \mathrm{Ca}$, and $30 \mathrm{~g} \mathrm{~kg}^{-1} \mathrm{P}$.

${ }^{\mathrm{b}}$ NEmf was calculate according to the Chinese Feeding Standard of Beef Cattle (NY/T815-2004). while the other nutrient levels were measured values.

$\mathrm{SRU}=$ Slow-release urea, $\mathrm{DM}=$ Dry matter, $\mathrm{CP}=$ Crude protein, $\mathrm{EE}=$ Ether extract, $\mathrm{NDF}=$ Neutral detergent fiber, $\mathrm{ADF}=\mathrm{Acid}$ detergent fiber.

\section{Sample collection}

The BW of each cattle was measured at day 0 , day 30 and day 60 in formal study period before morning feeding. The average daily gain (ADG) and daily dry matter intake (DMI) were calculated from day 0 to day 74 . The daily feed intake was calculated before the morning feeding each day by weighing the offered roughage and concentrate feed and determining the number of refusals. Feed samples were taken daily and frozen at $-20{ }^{\circ} \mathrm{C}$ for the determination of chemical composition. 
In day 74 , blood samples were collected from each cattle via jugular venepuncture using $5 \mathrm{ml}$ capacity evacuated blood-collecting tubes (YL003, Nanjing, China). After coagulation at room temperature for $30 \mathrm{~min}$, the blood samples were centrifuged at $3000 \mathrm{~g}$ for $10 \mathrm{~min}$ at $4{ }^{\circ} \mathrm{C}$. The serum samples were divided into tubes and stored at -20 ${ }^{\circ} \mathrm{C}$ for analysis.

Three cattle with similar BW were chosen from each group for the digestion trial. Total feces collection method was adopted in the digestion test. Beginning at $06: 00 \mathrm{~h}$ on day 72 , fecal samples $(300 \mathrm{~g})$ were collected by 6 -h intervals for $3 \mathrm{~d}$. Fecal samples were pooled by cattle, dried at 65 ${ }^{\circ} \mathrm{C}$, ground, and stored for the analysis of dry matter (DM), Kjeldahl nitrogen, neutral detergent fiber (NDF), acid detergent fiber (ADF), ether extract (EE), and ash. Fecal excretion and total tract apparent digestibility of dietary nutrients were calculated based on concentrations of acid insoluble ash (AIA) in feed and feces (Van Keulen \& Young, 1977).

\section{Analytical methods}

Feed and feces were dried at $65^{\circ} \mathrm{C}$ for $72 \mathrm{~h}$ and ground through a $1 \mathrm{~mm}$ screen using a Cyclotech Mill, (Tecator, Sweden) and then analyzed using standard methods of Official Method of Analysis [AOAC] (1995) for DM (ID 967.03), ash (ID 942.05) and EE (ID 954.02). Acid detergent fiber and neutral detergent fiber were determined according to the AOAC method (1995). After the total nitrogen was assayed via the Kjeldahl method (AOAC, 1997). Fecal excretion and total tract apparent digestibility of dietary nutrients were calculated based on concentrations of acid insoluble ash (AIA) in feed and feces (Van Keulen \& Young, 1977).

Blood biochemical parameters were measured by the Beijing Sino-UK Institute of Biological Technology in an automatic biochemical analyzer (7160; Hitachi, Ibarakiken,Japan) using a colorimetric method. The concentrations of glucose (GLU), uric acid(UA), total protein (TP), albumin
(ALB), blood ammonia and the activity of aspartic transaminase (AST), alkaline phosphatase (ALP), ALT and $\gamma$-glutamyl transpeptidase $(\gamma$-GGT) were measured in serum.

The activities of total superoxide dismutase (T-SOD) and GSH-Px and malondialdehyde (MDA) content in serum samples were measured using the kits from Nanjing Jiancheng Bioengineering Institute (Nanjing, China) according to the manufacturer's instructions of kits (Liu et al., 2013). The activity of T-SOD and GSH-Px were detected by the hydroxylamine method and colorimetric assay, respectively. The MDA content was detected by the thiobarbituric acid method.

The levels of IgG, IgA, IgM, T3, thyroxine (T4), growth hormone (GH), insulin-like growth factor-1 (IGF-1), and testosterone in serum samples were measured using the kits from Beijing Sino-uk institute of Biological Technology (Beijing, China) following the manufacturer's instructions. All measurements were performed at Beijing Sino-uk institute of Biological Technology.

\section{Statistical analysis}

All data were analyzed using a One-way ANOVA in SPSS 17.0 for Windows (SPSS Inc., Chicago, USA). Significance was declared at $P<$ 0.05 , and trends were discussed at $0.05<P<0.10$. When a significant effect of treatment was detected, differences among means were tested using LSD multiple comparison test.

\section{Results}

Effect of SRU on in vitro fermentation parameters in cultivated fluid

The in vitro fermentation parameters in cultivated fluid were shown in Table 3. The DM degradation rate (DMD) in SRU group was higher than that in the other two groups $(P<0.05)$. The $\mathrm{pH}$ value of SRU group and Urea group were lower than that of control group $(P<0.05)$, but there were no 
significant difference between these two groups ( $P$ $>0.05)$. The $\mathrm{NH}_{3}-\mathrm{N}$ concentration of SRU group was lower than that of the other groups $(P<0.05)$, and the $\mathrm{NH}_{3}-\mathrm{N}$ concentration of Urea group was higher than that of control group $(P<0.05)$, but there were no significant with the urea control $(P>0.05)$. The total VFA concentration and acetic acid concentration of Urea group were higher than those of the other two groups $(P<0.05)$, but there were no significant difference between control group and SUR group $(P>0.05)$. Compared with control group, the concentration of propionic acid in SRU group and Urea group were increased $(P<0.05)$, but there were no difference between these two groups $(P>0.05)$. The concentration of butyric acid in SRU group was lower than that in the other groups $(P<0.05)$, but there were no significant difference between control group and Urea group $(P>0.05)$. The acetate to propionate $(\mathrm{A} / \mathrm{P})$ of Urea group was lower than that of control group $(P<0.05)$.

Table 3

Effect of SRU on the in vitro fermentation parameters in cultivated fluid

\begin{tabular}{|c|c|c|c|c|c|}
\hline Items & Control group & SRU group & Urea group & SEM & $P$-value \\
\hline$\overline{\mathrm{DMD}(\%)}$ & $24.93^{\mathrm{a}}$ & $41.45^{\mathrm{b}}$ & $17.73^{\mathrm{a}}$ & 3.68 & 0.001 \\
\hline $\mathrm{pH}$ & $6.66^{\mathrm{b}}$ & $6.62^{\mathrm{a}}$ & $6.62^{\mathrm{a}}$ & 0.01 & 0.014 \\
\hline $\mathrm{NH}_{3}-\mathrm{N}\left(\mathrm{mg} \mathrm{dL}^{-1}\right)$ & $9.57^{b}$ & $6.55^{\mathrm{a}}$ & $10.17^{\mathrm{b}}$ & 0.68 & 0.034 \\
\hline TVFA (mmol L-1) & $104.24^{\mathrm{a}}$ & $103.33^{\mathrm{a}}$ & $108.57^{\mathrm{b}}$ & 0.93 & 0.014 \\
\hline Acetic acid $\left(\mathrm{mmol} \mathrm{L}^{-1}\right)$ & $72.91^{\mathrm{a}}$ & $73.88^{\mathrm{a}}$ & $77.51^{\mathrm{b}}$ & 0.79 & 0.010 \\
\hline Propionic acid (mmol L-1) & $18.90^{\mathrm{a}}$ & $20.05^{\mathrm{b}}$ & $19.53^{\mathrm{b}}$ & 0.18 & 0.006 \\
\hline Butyric acid $\left(\mathrm{mmol} \mathrm{L}^{-1}\right)$ & $12.43^{\mathrm{b}}$ & $9.39^{\mathrm{a}}$ & $11.54^{\mathrm{b}}$ & 0.48 & 0.002 \\
\hline $\mathrm{A} / \mathrm{P}$ & $3.86^{\mathrm{a}}$ & $3.69^{\mathrm{ab}}$ & $3.97^{\mathrm{b}}$ & 0.05 & 0.047 \\
\hline
\end{tabular}

$\dagger$ Different lowercase letters in the same row indicate significant differences $(P<0.05)$. SRU= Slow-release urea, SEM= The total standard error of the mean. $\mathrm{DMD}=$ The dry matter degradation rate, $\mathrm{TVFA}=$ Total volatile fatty acid, $\mathrm{A} / \mathrm{P}=\mathrm{The}$ proportion of acetic acid to propionic acid.

Effect of SRU on MCP concentration, DOM and MOEFF in culture fluid in vitro

As shown in Table 4, there were no significant difference in MCP concentration and DMNP production among the three groups $(P>0.05)$. The DOM of SRU group was significantly higher than that of the other two groups $(P<0.05)$, but there were no difference between control group and Urea group $(P>0.05)$. The MOEFF of SRU group was lower than that of the other groups $(P<0.05)$, but there were no difference between control group and Urea group $(P>0.05)$.

Table 4

Effect of SRU on MCP concentration, DOM and MOEFF in cultivated fluid in vitro

\begin{tabular}{lccccc}
\hline Items & Control group & SRU group & Urea group & SEM & $P$-value \\
\hline MCP $\left(\mathrm{mg} \mathrm{mL}^{-1}\right)$ & 0.28 & 0.28 & 0.27 & 0.004 & 0.263 \\
DMNP $\left(\mathrm{g} \mathrm{d}^{-1}\right)$ & 4.49 & 4.4 & 4.25 & 0.06 & 0.263 \\
DOM $\left(\mathrm{g} \mathrm{kg}^{-1}\right)$ & $283.1^{\mathrm{a}}$ & $425.73^{\mathrm{b}}$ & $236.9^{\mathrm{a}}$ & 30.25 & 0.002 \\
MOEFF $\left(\mathrm{g} \mathrm{kg}^{-1}\right)$ & $16.23^{\mathrm{b}}$ & $10.37^{\mathrm{a}}$ & $18.04^{\mathrm{b}}$ & 1.31 & 0.010 \\
\hline
\end{tabular}

$\dagger$ Different lowercase letters in the same row indicate significant differences $(P<0.05)$. SRU=Slow-release urea, SEM= The total standard error of the mean, $\mathrm{MCP}=$ Microbial protein, $\mathrm{DMNP}=$ The calculation of daily microbial nitrogen production, $\mathrm{DOM}=$ Digestible organic matter, MOEFF= Rumen microbial growth efficiency. 
Effect of SRU on Growth performance of beef cattle

As shown in Table 5, the initial body weight (BW) of three groups was similar at day $0(P>0.05$ for intergroup difference). The average dry matter intake (ADMI) of SRU group and Urea group were significantly lower than that of control group $(P<0.05)$ at day 30 and day 60 , but there were no significant difference between SRU group and Urea group $(P>0.05)$. There were no difference in average daily gain (ADG) and feed:gain $(\mathrm{F} / \mathrm{G})$ among three groups at day 30 and day $60(P>0.05)$. After a 60day feeding period, the average day gain (ADG) was $0.78 \mathrm{~kg}, 0.82 \mathrm{~kg}$ and $0.72 \mathrm{~kg}$ for the control group, SRU group, and urea group, respectively.

Table 5

Effects of dietary slow-release urea on growth performance in beef cattle

\begin{tabular}{ccccccc}
\hline & Items & Control group & SRU group & Urea group & SEM & $P$-value \\
\hline $0 \mathrm{~d}$ & Initial BW $(\mathrm{kg})$ & 313.17 & 316.33 & 318.00 & 7.30 & 0.963 \\
\hline \multirow{3}{*}{$30 \mathrm{~d}$} & ADG $(\mathrm{kg})$ & 0.85 & 0.88 & 0.76 & 0.04 & 0.573 \\
& ADMI $(\mathrm{kg})$ & $7.86^{\mathrm{a}}$ & $7.75^{\mathrm{b}}$ & $7.72^{\mathrm{b}}$ & 0.03 & 0.041 \\
& $\mathrm{~F} / \mathrm{G}$ & 9.33 & 8.86 & 10.86 & 0.69 & 0.527 \\
\hline \multirow{3}{*}{$60 \mathrm{~d}$} & ADG $(\mathrm{kg})$ & 0.78 & 0.82 & 0.72 & 0.04 & 0.617 \\
& ADMI $(\mathrm{kg})$ & $6.91^{\mathrm{a}}$ & $6.82^{\mathrm{b}}$ & $6.80^{\mathrm{b}}$ & 0.02 & 0.040 \\
& $\mathrm{~F} / \mathrm{G}$ & 8.95 & 8.37 & 9.76 & 0.47 & 0.541 \\
\hline
\end{tabular}

$\dagger$ Different lowercase letters in the same row indicate significant differences $(P<0.05)$. SRU $=$ Slow-release urea, SEM= The total standard error of the mean, $\mathrm{BW}=$ Body weight, $\mathrm{ADG}=\mathrm{The}$ average daily gain, $\mathrm{ADMI}=$ The average dry matter intake, $\mathrm{F} / \mathrm{G}=\mathrm{The}$ proportion of feed to gain.

\section{Effect of SRU on Nutrient digestibility of beef cattle}

The apparent digestibility of dry matter (DM) and organic matter $(\mathrm{OM})$ in SRU group and urea group were significantly higher than those of control group $(P<0.05)$, but there were no significant difference between SRU group and Urea group $(P>0.05)$. The apparent digestibility of ether extract (EE) in SRU group was significantly lower than that in control group $(P<0.05)$, and the apparent digestibility of EE in Urea group was significantly lower than that in SRU group $(P<0.05)$. No significant differences in the apparent digestibility of crude protein (CP), neutral detergent fiber (NDF) and acid detergent fiber (ADF)were found among the three groups $(P$ $>0.05$ ) (Table 6).

Table 6

Effects of dietary slow-release urea on nutrient digestibility in beef cattle

\begin{tabular}{lccccc}
\hline Items & Control group & SRU group & Urea group & SEM & $P$-value \\
\hline DM & $70.88^{\mathrm{b}}$ & $73.41^{\mathrm{a}}$ & $73.83^{\mathrm{a}}$ & 0.55 & 0.028 \\
$\mathrm{OM}$ & $74.81^{\mathrm{b}}$ & $77.22^{\mathrm{a}}$ & $77.54^{\mathrm{a}}$ & 0.52 & 0.031 \\
$\mathrm{CP}$ & 74.84 & 72.43 & 75.48 & 0.64 & 0.105 \\
$\mathrm{EE}$ & $77.36^{\mathrm{a}}$ & $64.48^{\mathrm{b}}$ & $51.76^{\mathrm{c}}$ & 3.95 & 0.002 \\
$\mathrm{NDF}$ & 74.28 & 73.74 & 71.54 & 0.62 & 0.163 \\
$\mathrm{ADF}$ & 62.71 & 62.26 & 60.93 & 0.43 & 0.289 \\
\hline
\end{tabular}

Units: \%

$\dagger$ Different lowercase letters in the same row indicate significant differences $(P<0.05)$. SRU= Slow-release urea, SEM= The total standard error of the mean, $\mathrm{DM}=$ Dry matter, $\mathrm{OM}=$ Organic matter, $\mathrm{CP}=$ Crude protein, $\mathrm{EE}=$ Ether extract, $\mathrm{NDF}=\mathrm{Neutral}$ detergent fiber, $\mathrm{ADF}=$ Acid detergent fiber. 
Effect of SRU on Serum metabolites of beef cattle

Supplementing SRU and Urea in diet did not affect the metabolites concentrations including glucose, uric acid, serum urea nitrogen, serum ammonia, total protein (TP), alkaline phosphatase (ALP) and $\gamma$-glutamyl transpeptidase $(\gamma$-GGT) in serum $(P>$ 0.05). Supplementing SRU tended to increase the concentration of albumin (ALB) and aspartate aminotransferase (AST) in serum compared with control group $(0.05<P<0.1)$, but supplementing urea tended to reduced the concentrations of ALB and AST in serum. The concentration of alanine aminotransferase (ALT) in serum was significantly lower in Urea group than those in SRU group $(P<$ 0.05) (Table 7).

Table 7

Effects of dietary slow-release urea on serum biochemical indices in beef cattle

\begin{tabular}{lccccc}
\hline Items & Control group & SRU group & Urea group & SEM & $P$-value \\
\hline Glucose $\left(\mathrm{mmol}^{\mathrm{L}-1}\right)$ & 4.72 & 4.57 & 4.40 & 0.13 & 0.619 \\
Uric acid (umol $\left.{ }^{\mathrm{L}-1}\right)$ & 39.37 & 38.81 & 43.45 & 1.38 & 0.333 \\
serum urea nitrogen $\left(\mathrm{mmol}^{\mathrm{L}-1}\right)$ & 5.36 & 5.28 & 4.52 & 0.19 & 0.127 \\
Serum ammonia $\left(\mathrm{mmol}^{\mathrm{L}-1}\right)$ & 21.88 & 22.75 & 23.07 & 0.29 & 0.253 \\
TP $\left(\mathrm{g}^{\mathrm{L}-1}\right)$ & 68.50 & 68.14 & 63.95 & 1.02 & 0.121 \\
ALB $\left(\mathrm{g}^{\mathrm{L}-1}\right)$ & 29.84 & 30.24 & 27.98 & 0.44 & 0.060 \\
AST $\left(\mathrm{U}^{\mathrm{L}-1}\right)$ & 56.92 & 60.19 & 49.42 & 2.13 & 0.087 \\
ALT $\left(\mathrm{U}^{\mathrm{L}-1}\right)$ & $21.62^{\mathrm{ab}}$ & $22.91^{\mathrm{a}}$ & $17.52^{\mathrm{b}}$ & 0.94 & 0.032 \\
ALP $\left(\mathrm{U}^{\mathrm{L}-1}\right)$ & 191.20 & 216.51 & 191.85 & 11.51 & 0.615 \\
$\gamma$-GGT $\left(\mathrm{U}^{\mathrm{L}-1}\right)$ & 17.09 & 15.88 & 15.78 & 0.64 & 0.695 \\
\hline
\end{tabular}

$\dagger$ Different lowercase letters in the same row indicate significant differences $(P<0.05)$. SRU= Slow-release urea, SEM= The total standard error of the mean, $\mathrm{TP}=$ Total protein, $\mathrm{ALB}=\mathrm{Albumin}, \mathrm{AST}=\mathrm{Ammonia}$ and the activity of aspartic transaminase, $\mathrm{ALT}=$ Alanine transaminase, $\mathrm{ALP}=$ Alkaline phosphatase, $\gamma$-GGT $=\gamma$-glutamyl transpeptidase.

The level of serum IgG was lower in the SRU group than that in the other two groups $(P<0.05)$, but there were no significant difference between control group and the Urea group $(P>0.05)$. The level of serum IgA in SRU group was significantly lower than that in Urea group $(P<0.05)$, and the level of serum IgA in Urea group was significantly lower than that in control group $(P<0.05)$. Compared with control group, supplementing SRU and urea in diet did not affect the levels of serum $\operatorname{IgM}(P>0.05)$ (Table 8$)$.

Table 8

Effects of dietary slow-release urea on serum immunological indices in beef cattle Units: $\mathrm{g}^{\mathrm{L}-1}$

\begin{tabular}{lccccc}
\hline Items & Control group & SRU group & Urea group & SEM & $P$-value \\
\hline IgG & $11.37^{\mathrm{a}}$ & $9.60^{\mathrm{b}}$ & $10.66^{\mathrm{a}}$ & 0.24 & 0.002 \\
IgA & $0.86^{\mathrm{a}}$ & $0.54^{\mathrm{c}}$ & $0.75^{\mathrm{b}}$ & 0.04 & $<0.001$ \\
IgM & 2.68 & 2.69 & 2.68 & 0.08 & 0.996 \\
\hline
\end{tabular}

Units: $\mathrm{g} \mathrm{L}^{-1}$

$\dagger$ Different lowercase letters in the same row indicate significant differences $(P<0.05)$. SRU= Slow-release urea, SEM= The total standard error of the mean, $\operatorname{IgG}=$ Immunoglobulin $\mathrm{G}, \mathrm{IgA}=$ Immunoglobulin $\mathrm{A}, \mathrm{IgM}=\mathrm{Immunoglobulin} \mathrm{M}$. 
Supplementing SRU and Urea did not affect the serum antioxidant indexes including T-SOD, SOD, and MDA $(P>0.05)$. The activity of GSHPxl in SRU group was significantly lower than

Table 9

Effects of dietary slow-release urea on serum antioxidant indices in beef cattle

\begin{tabular}{lccccc}
\hline Items & Control group & SRU group & Urea group & SEM $^{1}$ & $P$-value \\
\hline T-AOC $\left(\mathrm{U} \mathrm{ml}^{-1}\right)$ & 7.19 & 5.44 & 6.22 & 0.35 & 0.139 \\
GSH-Px $\left(\mathrm{U} \mathrm{ml}^{-1}\right)$ & $926.38^{\mathrm{a}}$ & $748.97^{\mathrm{b}}$ & $827.69^{\mathrm{ab}}$ & 27.24 & 0.021 \\
SOD $\left(\mathrm{U} \mathrm{ml}^{-1}\right)$ & 98.38 & 81.87 & 91.89 & 3.30 & 0.122 \\
MDA $\left(\mathrm{nmol} \mathrm{ml}^{-1}\right)$ & 3.22 & 3.73 & 3.41 & 0.13 & 0.301 \\
\hline
\end{tabular}

$\dagger$ Different lowercase letters in the same row indicate significant differences $(P<0.05)$. SRU $=$ Slow-release urea, SEM= The total standard error of the mean, T-AOC $=$ total antioxidant capacity, GSH-Px= glutathione peroxidase, $\mathrm{SOD}=$ total superoxide dismutase, $\mathrm{MDA}=$ malondialdehyde.

Compared with control group, supplementing SRU and urea significantly reduced the level of serum T3 $(P<0.05)$, but there were no significant difference between SRU group and Urea group $(P>0.05)$. Supplementing urea significantly reduced the concentration of serum $\mathrm{GH}$ compared that in control group $(P<0.05)$, but no significant difference were detected between SRU group and urea group $(P>0.05)$ (Table 9).

Table 10

Effects of dietary slow-release urea on serum endogenous hormones in beef cattle

\begin{tabular}{lccccc}
\hline Items & Control group & SRU group & Urea group & SEM $^{1}$ & $P$-value \\
\hline T4 & 91.69 & 81.64 & 82.94 & 2.98 & 0.372 \\
T3 & $1.07^{\mathrm{a}}$ & $0.78^{\mathrm{b}}$ & $0.84^{\mathrm{b}}$ & 0.03 & $<0.001$ \\
IGF-1 & 183.47 & 161.72 & 174.65 & 5.98 & 0.358 \\
GH & $9.71^{\mathrm{a}}$ & $8.31^{\mathrm{a}}$ & $6.70^{\mathrm{b}}$ & 0.41 & 0.004 \\
\hline
\end{tabular}

Units: ng ml-1

$\dagger$ Different lowercase letters in the same row indicate significant differences $(P<0.05)$. SRU $=$ Slow-release urea, SEM= The total standard error of the mean, T4= Thyroxine, T3= Thiiodothronine, IGF-1= Insulin-like growth factor-1, GH= Growth hormone.

\section{Discussion}

Effect of SRU on in vitro fermentation parameters in cultivated fluid

Rumen plays a vital role in the digestion and absorption of nutrients in ruminants due to a complex microbial community including anaerobic bacteria, archaea, ciliate protozoa and fungi with control group and SRU group $(P<0.05)$, no significant difference were detected in the concentration of serum GH between SRU group and control group $(P>0.05)$. There were no significant difference in the concentrations of serum $\mathrm{T} 4$ and IGF-I among three groups $(P>0.05)$ (Table 10). 
Schaefer, Liu, Axe and Meng (2010) and Gardinal et al. (2016). The $\mathrm{pH}$ value is one of the important and comprehensive indicators to reflect the rumen fermentation process. A suitable $\mathrm{pH}$ could improve the growth of microorganism. In this experiment, the $\mathrm{pH}$ value of cultivated fluid in vitro ranged from 6.62 to 6.66 , which were within the normal range (5.0 7.0) (Brown, Ponce, \& Pulikanti, 2006). This result indicated that under the conditions of this experiment, using an appropriate amount of SRU and urea to replace some of the soybean meal in diet had no adverse effect on the internal environment stability in rumen of beef cattle. This was consistent with the results of Chizzotti et al. (2008), in which adding urea in steers diet had no effect on rumen health. The optimum $\mathrm{NH}_{3}-\mathrm{N}$ concentration for the growth of rumen microorganism ranged from 5 to $28 \mathrm{mg} d L^{-1}$ (Wanapat, \& Pimpa, 1999; Perdok, Leng, Bird, Habib, \& Van Houtert, 1988). The $\mathrm{NH}_{3}-\mathrm{N}$ concentration of three groups in this experiment were all within the appropriate range. And SRU group had the lowest $\mathrm{NH}_{3}-\mathrm{N}$ concentration, which indicated that SRU could not only achieve a good sustained release effect, but also facilitate the better utilization of ammonia by rumen microorganisms. This result was consistent with the reports of Wang, Zhao, Nan, Jin and Wang (2018) and Benedeti et al. (2014).

As the main fermentation product of carbohydrates in rumen, VFAs are mainly composed of acetic acid, propionic acid and butyric acid. The yield and composition ratio of VFA could effectively reflect the ability of ruminants to absorb and utilize nutrients (Liang et al., 2018). The results of this experiment found that using SRU to alternative some soybean meal in diet did not affect the TVFA concentration and acetic acid concentration of beef cattle, which is consistent with the previous studies. But the concentration of propionic acid in SRU group and urea group was significantly higher than that in control group, which was consistent with the results of Bannink et al. (2010). Xin et al. (2010) studied the effect of SRU and soy protein in diet on the VFA concentration of Holstein cow, the results showed that there were no difference in TVFA concentration, VFA composition and acetic acid/propionic acid ratio between the SRU group and the soybean group. The rumen fermentation could be divided into acetic acid fermentation and propionic acid fermentation according to the acetic acid/propionic acid ratio. Carrico et al. (2005) found that the proportion of acetic acid to propionic acid could not only affect the energy utilization of rumen microorganisms, but also affect the synthesis of microbial proteins and the population structure of different microorganisms. Bannink et al. (2010) thought that propionic acid fermentation can provide more energy for the body. In this experiment, the ratio of acetic acid to propionic acid in urea group was significantly higher than that in control group, and the rumen fermentation type was changed from acetic acid fermentation to propionic acid fermentation. However, the SRU group did not change the fermentation type of rumen. Butyric acid was a kind of short-chain fatty acid, which was the fermentation product of plant matter (such as cellulose, fiber, etc.) by rumen microorganisms. The decrease of butyric acid concentration in rumen might be related to the conversion of acetic acid and butyric acid (Sutton et al., 2003).

The rumen fermentation products such as VFA, $\mathrm{NH}_{3} \mathrm{H}$ and ATP could be utilized to synthesize microbial protein (MCP) by rumen microorganisms. The MCP content was an important indicator to measure the activity of rumen microorganisms and reflect the rumen fermentation function. Galo, Emanuele, Sniffen, White, \& Knapp (2003) and Klusmeyer, McCarthy, Clark and Nelson (1990) found that adding SRU in dairy diets had less effect on the synthesis of MCP in rumen. In the present study, supplementing SRU to replace some soybean meal did not affect the amount of MCP in cultivated fluid in vitro of beef cattle, which is consistent with previous researches.

Benedeti et al. (2014) and Stokes, Hoover, Miller and Blauweikel (1991) reported that supplementing 
SRU in diet could improve the utilization of dietary organic matter (OM) in dairy cow. These results were consistent with the present study. Besides, the current results showed that replacing some soybean meal with SRU in diet could improve the utilization of DOM, but SRU did not affect the microbial nitrogen production, which resulted in a decrease in MOEEF. This result was consistent with the study by Xin et al. (2010). National Research Council (NRC) data show that the rumen MOEEF ranged from 12 to $54 \mathrm{~g} \mathrm{~kg}^{-1}$. Compared with NRC, the current result had a lower MOEEF. We suspect that this result might be related to the difference between in vitro simulated conditions and rumen fermentation in vivo.

\section{Effect of SRU on growth performance of beef cattle}

The DMI in the SRU group was significantly lower than that in soybean meal group, which was inconsistent with the previous studies. Considering the DMI of beef cattle was affected by many factors such as the processing technology of SRU, the age of beef cattle and the development status of rumen, the reason for the decline in feed intake of beef cattle need to be further studied. However, Xin et al. (2010) found that there were no difference in DMI between the polyurethane-coated urea group and soya bean meal group in cows. The DMI and ADG of beef steers were not affected by supplementing coated urea in diet (Pinos-Rodríguez, Peña, González-Muñoz, Bárcena, \& Salem, 2010). TaylorEdwards et al. (2009) observed that supplementing $1.2 \%$ SRU in diet did not affect the DMI, ADG and $\mathrm{F} / \mathrm{G}$ of finishing cattle compared with that feeding the soybean meal. These researches are consistent with the current study.

\section{Effect of SRU on nutrient digestibility of beef cattle}

No significant differences were found in the apparent digestibility of CP, NDF and ADF of beef cattle among three groups in this study, which was consistent with results of Benedeti et al. (2014). The apparent digestibility of DM in SRU group and Urea group were significantly higher than those in control group, which was not consistent with the results of Benedeti et al. (2014) and Lizarazo et al. (2014). Galina, Perez-Gil, Ortiz, Hummel, \& Ørskov (2003) reported that the DM digestibility of beef cattle was significantly increased by feeding $1.8 \mathrm{~kg} / \mathrm{d}$ SRU in diet, which was consistent with the present study. These different results showed that there were no consistent effects of SRU on the apparent digestibility of DM in ruminants. The reason might be related to the nitrogen content in ruminant diets. In a low-nitrogen diet, adding appropriate amount of urea could stimulate the growth of microorganisms and then improve the digestibility of DM, while excessive urea will inhibit the utilization of DM for rumen microorganisms. Besides, the apparent digestibility of EE was affected by supplementing SRU and urea in the current study. This result might be related to the component of SRU. The SRU that used in the present study was coated by palm oil, whose main ingredients were saturated fatty acids. The saturated fatty acids are hydrophobic fatty acids with low water solubility (Bianchi et al., 2014), which might affects the utilization of EE by rumen microorganisms. Furthermore, saturated fatty acids could also reduce the number of bacteria in the rumen (Griswold, Apgar, Bouton, \& Firkins 2003; Wang et al., 2018; Norrapoke et al., 2018).

\section{Effect of SRU on serum metabolites of beef cattle}

Safety was the first element of feed production. Serum biochemical indices were the important indicator to reflect the animal physiological function and health status. In the present study, serum biochemical indices of beef cattle such as glucose, ALP, $\gamma$-GGT, urea, and ALB were not affected by supplementing SRU and urea in diet, which was consistent with the previous researches. Huntington, Harmon, Kristensen, Hanson, \& Spears (2006) found that supplementing SRU in diet did 
not affect the serum urea nitrogen level of cattle. The levels of serum ALP and glucose in sheep were unaffected until the dosage of urea phosphate was higher than $4 \%$ in the concentrate feed ( $\mathrm{Ji}$ et al., 2017). Goulart et al. (2013) observed that the concentration of $\gamma$-GGT, urea, and ALB were not differed in cows after feeding SRU diet and urea diet.

It is well known that SRU can be used as a substitute for protein feed in ruminants (Goulart et al., 2013; Inostroza, Shaver, Cabrera, \& Tricárico, 2010; Highstreet, Robinson, Robison, \& Garrett, 2010), but little information is available about its effect on serum immunity in beef cattle. The immune response is closely related to health of animals (Ingvartsen \& Moyes, 2013). The concentrations of serum immunoglobulin were one of the most common assessments of immune competence. Circulating IgG and IgM played important roles in anti-infection through engaging the phagocytic system and activating the complement system, while IgA can inhibit phagocytosis, chemotaxis, antibodydependent cellular cytotoxicity, and the release of inflammatory cytokines (Wolf et al., 1994). In the present study, SRU significantly decreased the levels of serum IgG and IgA, which meant that addition of SRU in diet might affect the immune function of beef cattle. But the reasons remain unclear and need to be further studied.

Free radicals in serum played important roles in immunity and signal transduction, but excessive free radicals could result in the lipid peroxidation in the cell membrane (Turner et al., 2004). Free radicals in body are eliminated by antioxidant enzymes including T-SOD, GSH-Px, catalase, etc. (Kurata, Suzuki, \& Agar, 1993). Thus, the antioxidative function could be evaluated by the activities of antioxidant enzymes. The current study showed that supplementing SRU decreased the activities of GSH-Px, but did not affect serum antioxidant indices including T-SOD, SOD, and MDA. The present results suggested that SRU might affect the antioxidant function of beef cattle for a long time.
As we all know that GH and IGF-I played large roles in controlling body growth and development (Schoenle, Zapf, Humbel, \& Froesch, 1982; Baker, Liu, Robertson, \& Efstratiadis, 1993). Researches had indicated that estrogen could affect the GH/ IGF-I axis functions (Leung, Johannsson, Leong, \& Ho, 2004). Breier, Gluckman, \& Bass (1988) and Coxam et al. (1990) reported that exogenous estrogen enhanced serum concentrations of GH and IGF-I in cattle. In the present study, supplementing urea significantly reduced serum GH concentration compared with control group and SRU group. This was why the ADG of urea group was lower than that of control group and SRU group. But supplementation of SRU did not affect the growth performance of beef cattle. In the present study, supplementing SRU and urea reduced the production of T3, which might be due to the inhibitory effect of urea on activities of GSH-Px. Thyroid peroxidase catalyzes iodination of tyrosyl residues on thyroglobulin and the ensuing oxidative coupling to yield T3 (Doerge \& Chang, 2002).

\section{Conclusions}

The replacement of some soybean meal by SRU in diet had no adverse impact on rumen fermentation, growth performance, and serum metabolites of beef cattle.

\section{Acknowledgements}

This work was supported by the National Key Research and Development Program of China (2018YFD0501804) and National Beef Cattle Industry Technology \& System [CARS-37].

\section{References}

Baker, J., Liu, J. P., Robertson, E. J., \& Efstratiadis, A. (1993). Role of insulin-like growth factors in embryonic and postnatal growth. Cell, 75(1), 73-82. doi: 10.1016/s0092-8674(05)80085-6 
Bannink, A., France, J., Lopez, S., Gerrits, W. J. J., Kebreab, E., Dijkstra, J. \& Tamminga, S. (2007). Modelling the implications of feeding strategy on rumen fermentation and functioning of the rumen wall. Animal Feed Science and Technology, 143(1), 3-26. doi: 10.1016/j.anifeedsci.2007.05.002

Benedeti, P. D. B., Paulino, P. V. R., Marcondes, M. I., Valadares, S. C., Fo., Martins, T. S., Lisboa, E. F.,... \& Duarte, M. S. (2014). Soybean meal replaced by slow release urea in finishing diets for beef cattle. Livestock Science, 165(1), 51-60. doi: 10.1016/j. livsci.2014.04.027

Bianchi, A. E., Macedo, V. P., França, R. T., Lopes, S. T., Lopes, L. S., Stefani, L. M., ... \& Silva, A. S. da. (2014). Effect of adding palm oil to the diet of dairy sheep on milk production and composition, function of liver and kidney, and the concentration of cholesterol, triglycerides and progesterone in blood serum. Small Ruminant Research, 117(1), 78-83. doi: 10.1016/j.smallrumres.2013.12.025

Breier, B. H., Gluckman, P. D., \& Bass, J. J. (1988). Influence of nutritional status and oestradiol-17 $\beta$ on plasma growth hormone, insulin-like growth factors-I and-II and the response to exogenous growth hormone in young steers. Journal of Endocrinology, 118(2), 243-250. doi: 10.1677/ joe.0.1180243 10.1677/joe.0.1180243

Brown, M. S., Ponce, C. H., \& Pulikanti, R. (2006). Adaptation of beef cattle to high-concentrate diets: Performance and ruminal metabolism. Journal of Animal Science, 84(13), 25-33. doi: $10.2527 / 2006.8413$ supple25x

Cappellozza, B. I., Bohnert, D. W., Schauer, C. S., Falck, S. J., Vanzant, E. S., Harmon, D. L., \& Cooke, R. F. (2013). Daily and alternate day supplementation of urea or soybean meal to ruminants consuming lowquality cool-season forage: II. Effects on ruminal fermentation. Livestock Science, 155(3), 214-222. doi: 10.1016/j.livsci.2013.05.002

Carrico, J. A., Pinto, F. R., Simas, C., Nunes, S., Sousa, N. G., Frazao, N., \& Almeida, J. S. (2005). Assessment of band-based similarity coefficients for automatic type and subtype classification of microbial isolates analyzed by pulsed-field gel electrophoresis. Journal of Clinical Microbiology, 43(11), 5483-5490. doi: 10.1128/jcm.43.11.5483-5490.2005

Cherdthong, A., Wanapat, M., \& Wachirapakorn, C. (2011). Influence of urea-calcium mixtures as rumen slow-release feed on in vitro fermentation using a gas production technique. Archives of Animal Nutrition, 65(3), 242-254. doi: 10.1080/1745039x.2011.568277
Chizzotti, F. H. M., Pereira, O. G., Tedeschi, L. O., Valadares, S. C., Fo., Chizzotti, M. L., Leao, M. I., \& Pereira, D. H. (2008). Effects of dietary nonprotein nitrogen on performance, digestibility, ruminal characteristics, and microbial efficiency in crossbred steers. Journal of Animal Science, 86(5), 1173-1181. doi: $10.2527 /$ jas.2006-654

Cone, J. W., van Gelder, A. H., Visscher, G. J., \& Oudshoorn, L. (1996). Influence of rumen fluid and substrate concentration on fermentation kinetics measured with a fully automated time related gas production apparatus. Animal Feed Science and Technology, 61(1-4), 113-128. doi: 10.1016/03778401(96)00950-9

Coxam, V., Davicco, M. J., Durand, D., Bauchart, D., Opmeer, F., \& Barlet, J. P. (1990). Steroid hormone may modulate hepatic somatomedin $\mathrm{C}$ production in newborn calves. Neonatology, 58(1), 16-23. doi: $10.1159 / 000243226$

Doerge, D. R., \& Chang, H. C. (2002). Inactivation of thyroid peroxidase by soy isoflavones, in vitro and in vivo. Journal of Chromatography B, 777(1-2), 269279. doi: 10.1016/s1570-0232(02)00214-3

Galina, M. A., Perez-Gil, F., Ortiz, R. M. A., Hummel, J. D., \& Ørskov, R. E. (2003). Effect of slow release urea supplementation on fattening of steers fed sugar cane tops (Saccharum officinarum) and maize (Zea mays): ruminal fermentation, feed intake and digestibility. Livestock production science, 83(1), 1-11. doi: 10.1016/s0301-6226(03)00045-9

Galo, E., Emanuele, S. M., Sniffen, C. J., White, J. H., \& Knapp, J. R. (2003). Effects of a polymer-coated urea product on nitrogen metabolism in lactating Holstein dairy cattle. Journal of Dairy Science, 86(6), 21542162. doi: 10.3168/jds.s0022-0302(03)73805-3

Gardinal, R., Calomeni, G. D., Cônsolo, N. R. B., Takiya, C. S., Freitas, J. E., Jr., Gandra, J. R., \& Rennó, F. P. (2016). Influence of polymer-coated slow-release urea on total tract apparent digestibility, ruminal fermentation and performance of Nellore steers. Asian-Australasian Journal of Animal Sciences, 30(1), 34. doi: 10.5713/ajas.16.0058

Goulart, M. A., Montagner, P., Lopes, M. S., Azambuja, R. D. C., Schwegler, E., Antunes, M. M., \& del Pino, F. A. B. (2013). Milk composition, ruminal $\mathrm{pH}$ and metabolic parameters of dairy cows supplemented with slow-release urea. Acta Scientiae Veterinariae, 41(1), 1-13. doi: 10.21608/jsas.2017.3492

Grant, J. L. (1979). Urea in supplements for growing young cattle on veld grazing in the dry season. South 
African Journal of Animal Science, 9(1), 33-39. doi: $10.1017 / \mathrm{s} 0021859600010121$

Griswold, K. E., Apgar, G. A., Bouton, J., \& Firkins, J. L. (2003). Effects of urea infusion and ruminal degradable protein concentration on microbial growth, digestibility, and fermentation in continuous culture. Journal of Animal Science, 81(1), 329-336. doi: $10.2527 / 2003.811329 x$

Highstreet, A., Robinson, P. H., Robison, J., \& Garrett, J. G. (2010). Response of Holstein cows to replacing urea with with a slowly rumen released urea in a diet high in soluble crude protein. Livestock Science, 129(1-3), 179-185. doi: 10.1016/j.livsci.2010.01.022

Huang, Y., Zou, C., Wei, S., Liang, X., Li, S., Lu, T., \& Liang, X. (2014). Effects of cysteamine on ruminal fermentation parameters and methane production of water buffalo by in vitro gas production method. Chinese Journal of Animal Nutrition, 26(1), 125133. doi: 10.1093/jas/skz258.585

Huntington, G. B., Harmon, D. L., Kristensen, N. B., Hanson, K. C., \& Spears, J. W. (2006). Effects of a slow-release urea source on absorption of ammonia and endogenous production of urea by cattle. Animal Feed Science and Technology, 130(3-4), 225-241. doi: 10.1016/j.anifeedsci.2006.01.012

Ingvartsen, K. L., \& Moyes, K. (2013). Nutrition, immune function and health of dairy cattle. Animal, 7(s1), 112-122. doi: 10.1017/s175173111200170x

Inostroza, J. F., Shaver, R. D., Cabrera, V. E., \& Tricárico, J. M. (2010). Effect of diets containing a controlledrelease urea product on milk yield, milk composition, and milk component yields in commercial Wisconsin dairy herds and economic implications. The Professional Animal Scientist, 26(2), 175-180. doi: 10.15232/s1080-7446(15)30577-5

Ji, S. K., Zhang, F., Sun, Y. K., Deng, K. D., Wang, B., Tu, Y., ... \& Diao, Q. Y. (2017). Influence of dietary slow release urea on growth performance, organ development and serum biochemical parameters of mutton sheep. Journal of Animal Physiology and Animal Nutrition, 101(5), 964-973. doi: 10.1111/ jpn. 12532

Jin, D., Zhao, S. G., Zheng, N., Bu, D. P., Beckers, Y., \& Wang, J. Q. (2018). Urea nitrogen induces changes in rumen microbial and host metabolic profiles in dairy cows. Livestock Science, 210(1), 104-110. doi: 10.1016/j.livsci.2018.02.011

Klusmeyer, T. H., McCarthy, R. D., Jr., Clark, J. H., \& Nelson, D. R. (1990). Effects of source and amount of protein on ruminal fermentation and passage of nutrients to the small intestine of lactating cows. Journal of Dairy Science, 73(12), 3526-3537. doi: 10.3168/jds.s0022-0302(90)79052-2

Kurata, M., Suzuki, M., \& Agar, N. S. (1993). Antioxidant systems and erythrocyte life-span in mammals. Comparative Biochemistry and Physiology Part B: Comparative Biochemistry, 106(3), 477-487. doi: 10.1016/0305-0491(93)90121-k

Leung, K. C., Johannsson, G., Leong, G. M., \& Ho, K. K. (2004). Estrogen regulation of growth hormone action. Endocrine reviews, 25(5), 693-721. doi: 10.1016/s1096-6374(08)70045-5

Liang, H., Xu, L. J., Zhao, X. H., Bai, J., Chen, Z. D., Zhou, S.,... Qu, M. R. (2018). Effect of daidzein on fermentation parameters and bacterial community of finishing Xianan cattle. Italian Journal of Animal Science, 17(4), 950-958. doi: 10.1080/1828051X.2018.1431965

Liu, D. Y., He, S. J., Jin, E. H., Liu, S. Q., Tang, Y. G., Li, S. H., \& Zhong, L. T. (2013). Effect of daidzein on production performance and serum antioxidative function in late lactation cows under heat stress. Livestock Science, 152(1), 16-20. doi: 10.1016/j. livsci.2012.12.003

Lizarazo, A. C., Mendoza, G. D., Kú, J., Melgoza, L. M., \& Crosby, M. (2014). Effects of slow-release urea and molasses on ruminal metabolism of lambs fed with low-quality tropical forage. Small Ruminant Research, 116(1), 28-31. doi: 10.1016/j. smallrumres.2013.10.009

Ma, W., Ren, L., Wang, L., Ding, J., Zhao, J., \& Meng, Q. (2011). Effect of supplemental levels of gelatinized starch-urea on growth performance and plasma biochemical indices of growing-finishing beef cattle. Chinese Journal of Animal Nutrition, 23(10), 17101715. doi: 10.13188/2325-4645.1000036

Makkar, H. P. S., Sharma, O. P., Dawra, R. K., \& Negi, S. S. (1982). Simple determination of microbial protein in rumen liquor. Journal of Dairy Science, 65(11), 2170-2173. doi: 10.3168/jds.s0022-0302(82)824776

National Research Council (2007). Committee on Nutrient Requirements of Small Ruminants, National Research Council, Committee on the Nutrient Requirements of Small Ruminants, Board on Agriculture, Division on Earth, \& Life Studies. Nutrient requirements of small ruminants: sheep, goats, cervids, and new world camelids. Washington, DC: National Academy Press. 
Norrapoke, T., Wanapat, M., Cherdthong, A., Kang, S., Phesatcha, K., \& Pongjongmit, T. (2018). Improvement of nutritive value of cassava pulp and in vitro fermentation and microbial population by urea and molasses supplementation. Journal of Applied Animal Research, 46(1), 242-247. doi: 10.1080/09712119.2017.1288630

Official Method of Analysis (1995). Animal Feeds: Association of Official Analytical Chemists (16nd ed.). Gaithersburg, MD: AOAC International.

Official Methods of Analysis of the Association of Official Analytical Chemists (1997). Animal Feeds: Association of Official Analytical Chemists (16nd ed.). Gaithersburg, MD: AOAC International.

Perdok, H. B., Leng, R. A., Bird, S. H., Habib, G., \& Van Houtert, M. (1988). Improving livestock production from straw-based diets. In E. F. Thomson, \& F. S. Thomson (Eds.), Increasing small ruminant productivity in semi-arid areas (pp. 81-91). Springer, Dordrecht.

Pinos-Rodríguez, J. M., Peña, L. Y., González-Muñoz, S. S., Bárcena, R., \& Salem, A. (2010). Effects of a slow-release coated urea product on growth performance and ruminal fermentation in beef steers. Italian Journal of Animal Science, 9(1), 4. doi: 10.4081/ijas.2010.e4

Ribeiro, S. S., Vasconcelos, J. T., Morais, M. G., Ítavo, C. B. C. F., \& Franco, G. L. (2011). Effects of ruminal infusion of a slow-release polymer-coated urea or conventional urea on apparent nutrient digestibility, in situ degradability, and rumen parameters in cattle fed low-quality hay. Animal Feed Science and Technology, 164(2), 53-61. doi: 10.1016/j. anifeedsci.2010.12.003

Schoenle, E., Zapf, J., Humbel, R. E., \& Froesch, E. R. (1982). Insulin-like growth factor I stimulates growth in hypophysectomized rats. Nature, 296(5854), 252253. doi: $10.1038 / 296252 \mathrm{a} 0$

Stokes, S. R., Hoover, W. H., Miller, T. K., \& Blauweikel, R. (1991). Ruminal digestion and microbial utilization of diets varying in type of carbohydrate and protein. Journal of Dairy Science, 74(3), 871881. doi: 10.3168/jds.s0022-0302(91)78236-2

Sutton, J. D., Dhanoa, M. S., Morant, S. V., France, J., Napper, D. J., \& Schuller, E. (2003). Rates of production of acetate, propionate, and butyrate in the rumen of lactating dairy cows given normal and low-roughage diets. Journal of Dairy Science, $86(11), \quad 3620-3633$. doi: $10.3168 /$ jds.s00220302(03)73968-x
Taylor-Edwards, C. C., Elam, N. A., Kitts, S. E., McLeod, K. R., Axe, D. E., Vanzant, E. S.,... \& Harmon, D. L. (2009). Influence of slow-release urea on nitrogen balance and portal-drained visceral nutrient flux in beef steers. Journal of Animal Science, 87(1), 209221. doi: $10.2527 /$ jas.2008-0913

Turner, R., Baron, T., Wolffram, S., Minihane, A. M., Cassidy, A., Rimbach, G., \& Weinberg, P. D. (2004). Effect of circulating forms of soy isoflavones on the oxidation of low density lipoprotein. Free Radical Research, 38(2), 209-216. doi: 10.1080/10715760310001641854

Van Keulen, J. Y. B. A., \& Young, B. A. (1977). Evaluation of acid-insoluble ash as a natural marker in ruminant digestibility studies. Journal of Animal Science, 44(2), 282-287. doi: 10.2527/jas1977.442282x

Wanapat, M., \& Pimpa, O. (1999). Effect of ruminal NH3-N levels on ruminal fermentation, purine derivatives, digestibility and rice straw intake in swamp buffaloes. Asian-Australasian Journal of Animal Sciences, 12(6), 904-907. doi: 10.5713/ ajas.1999.904

Wang, P., Zhao, S., Nan, X., Jin, D., \& Wang, J. (2018). Influence of hydrolysis rate of urea on ruminal bacterial diversity level and cellulolytic bacteria abundance in vitro. PeerJ, 6(1), e5475. doi: 10.7717/ peerj. 5475

Weatherburn, M. W. (1967). Phenol-hypochlorite reaction for determination of ammonia. Analytical Chemistry, 39(8), 971-974. doi: 10.1021/ac60252a045

Wolf, H. M., Fischer, M. B., Puhringer, H., Samstag, A., Vogel, E., \& Eibl, M. M. (1994). Human serum IgA downregulates the release of inflammatory cytokines (tumor necrosis factor-alpha, interleukin-6) in human monocytes. Blood, 83(5), 1278-1288. doi: 10.1182/ blood.v83.5.1278.1278

Wright, A. D. G., \& Klieve, A. V. (2011). Does the complexity of the rumen microbial ecology preclude methane mitigation? Animal Feed Science and Technology, 166(1), 248-253. doi: 10.1016/j. anifeedsci.2011.04.015

Xin, H. S., Schaefer, D. M., Liu, Q. P., Axe, D. E., \& Meng, Q. X. (2010). Effects of polyurethane coated urea supplement on in vitro ruminal fermentation, ammonia release dynamics and lactating performance of Holstein dairy cows fed a steam-flaked corn-based diet. Asian-Australasian Journal of Animal Sciences, 23(4), 491-500. doi: 10.5713/ajas.2010.90153 